\title{
The Impacts of Carbon Emission Disclosure, Environmental Performance, and Social Performance on Financial Performance (Empirical Studies in Proper Participating Companies Listed in Indonesia Stocks Exchange, Year 2013-2016)
}

\section{Noorlailie Soewarno, Bambang Tjahjadi, and Ria Hanifah Firdausi}

Universitas Airlangga, Indonesia

\section{Abstract}

This study aims to examine the impacts of carbon emission disclosure, environmental performance, and social performance on financial performance of PROPER participating

Corresponding Author: Noorlailie Soewarno noorlailie@gmail.com

Received: 29 August 2018 Accepted: 18 September 2018 Published: 11 November 2018

Publishing services provided by Knowledge

(c) Noorlailie Soewarno et al. This article is distributed under the terms of the

Commons Attribution License, which permits unrestricted use and redistribution provided that the original author and source are credited.

Selection and Peer-review under the responsibility of the ICOI-2018 Conference Committee companies listed in Indonesia Stocks Exchange during the years 2013-2016. Methods to measure the carbon emission disclosure are obtained from checklists based on the requisition sheet of the Carbon Disclosure Project (CDP). The environmental performance is measured using PROPER assessment results retrieved from the annual reports, as well as the sustainability reports. The social performance is assessed using social reporting performance scores through the analysis that is given by the Global Reporting Initiative (GRI) G4 Guidelines. Meanwhile, financial performance is measured using Return on Asset (ROA). The samples in this study are applied using purposive sampling, and 87 PROPER participating companies listed in Indonesia Stocks Exchange during the years 2013-2016 have been obtained. The results of this study show that the carbon emission disclosure, and environmental performance have significant positive impacts on the financial performance, meanwhile the social performance does not significantly influence the financial performance.

Keywords: carbon emission disclosure, environmental performance, social performance, financial performance

\section{Introduction}

Global warming has become an increasingly important political and business issue for most countries [6]. Global warming is defined as a remarkable rise of earth surface temperature which is primarily caused by the greenhouse gases released by humans after burning fossil fuels [28]. The greatest human activity contributing to greenhouse gas emissions would be industrial activity. Wasteful utilisation of energy and carbon 
gas disposal from production processes can be identified as negative consequences of factories' daily operations [34]. According to Anggraeni (2015), some companies had claimed that their end products were categorised as environmentally friendly; however, those industrial entities had not provided sufficient explanations regarding their efforts to reduce the environmental degradation. There are strong warnings by environmental, business and political leaders in responding to the challenges which threaten through the global warming. One of the challenges in the threat of global warming is that entities are urged to understand and communicate their contributions to global warming due to carbon emissions [6]. Efforts of the international community to face the climate change phenomenon began with the signing of the United Nation Framework Convention on Climate Change (UNFCCC) [21]. Several countries have ratified the Kyoto Protocol, including Indonesia through the Laws of the Republic of Indonesia Number 17 Year 2004, in order to implement continuous development and take part in the efforts to reduce greenhouse gas emissions (Jannah \& Muid, 2014). The implications of the Kyoto Protocol create carbon accounting, which is an obligation for companies to admit, measure, record, present and disclose their carbon emissions [19].

Environmental issues have been growing very rapidly [24]. The initial concern is the occurrence of environmental damage resulting in pollution, water contamination and climate change. In order to preserve the environment, companies are expected to decrease their consumption of natural resources by changing the technologies into environmentally friendly ones. The environmental performance is the performance of companies that care about the surrounding environment by producing environmentally friendly products [9]. Environmental performance is a demand that companies must respond to as a result of the pressure by employees, people, communities who concern about environment and government as the regulator [16]. According to Elkington (1997: 72), the basic goal of every company is to gain profit and advantage. In order to guarantee its business sustainability, a company must not only focus on getting profit, but also care about the condition of society and environment. By preserving the environment, the company is able to gain benefit indirectly, both in terms of health and convenience, as well as resources availability.

The current business situation makes stakeholders observe the company's performance not only from financial performance points of view, but also from non-financial performance [10]. According to Deegan and Bloomquist (2006), stakeholders can basically control or possess the ability to influence the company's consumption of economic resources. Therefore, the powers of stakeholders are determined by the size of powers they have over those resources. Such powers can be the ability to restrict 
the numbers of users of limited economic resources (capital and labour), the access to influential media, the ability to govern the company, or the ability to affect the consumption of goods or services produced by the company [7]. According Suparjan and Mulya (2012), a company where stakeholders think it has a good reputation will make it easier for the company to pass the market mechanism to reach a good financial position as well. If the company is able to balance the interests of shareholders, the company will have constant support; therefore, increasing its market shares growth, sales and profits ([22]: 5).

This study was conducted to determine whether there are impacts among disclosure of carbon emissions, environmental performance and social performance on financial performance, given the disclosure of greenhouse gas emissions in Indonesia is still considered as voluntary, and the practice is still rarely done by business entities. In addition, this study was also conducted to understand whether the results to be obtained later are closely similar or different to the previous studies.

\section{Theory and Hypothesis}

\subsection{The impact of carbon emission disclosure and financial performance}

The theory used as a fundamental of carbon emission disclosure is the theory of legitimacy [19]. According to Berthelot and Robert (2011), environmental disclosure is one among many ways of organisations to gain legitimacy. The theory of legitimacy focuses on the relationship between a company and society through the regulations made by the government [19]. When there is a difference between the company and society, which is related to the value held by the 'legitimation gap', then at that time, the company's legitimacy is in a threatened position and may affect its ability to continue its business activities. The biggest threat is that people will revoke their social contracts when they feel dissatisfied with the company's activities.

Companies included in carbon-intensive industries will be more likely to disclose their carbon information to demonstrate that they are responsible for it and to reduce the threat to their legitimacy [3]. The number of companies' Return on Assets (ROA) can also encourage them to reveal their environmental disclosure, one of which is the disclosure of greenhouse gas emissions. The practice of carbon emissions disclosure in Indonesia is still considered as voluntary [19]. Healy and Palepu (2001) claimed that voluntary disclosure by companies is able to improve the quality of their financial 
statements so that potential investors are willing to invest. Research by Liu et al. (2016) mentioned that carbon emissions have small negative impacts, but are statistically significant on the company's financial performance. This is caused by the lower carbon emissions that are able to increase shareholder wealth as well as to gain higher profit compared to the return of their tangible assets. Reduction in carbon emissions allows companies to lower their operating costs, improve their reputation, increase stakeholders' loyalty and improve their financial performance. Based on the aforementioned conclusions and statements regarding the impacts of carbon emissions disclosure on financial performance, the formulation of the hypothesis is as follows:

\section{$\mathrm{H}_{1}$ : Carbon Emission Disclosure positively affects the Financial Performance}

\subsection{The impact of environmental performance and financial performance}

Environmental performance is a demand that companies must fulfil as a result of the pressures of employees, people, communities who concern about environment and also government as regulators [16]. Porter and Linde (1995) suggested that environmental performance improvement is an important source of information for companies to achieve efficient production levels, productivity improvements complying with safety standards, cost reduction caused by environmental degradation and opportunities to find new markets. The statement is supported by triple bottom line theory which states that the basic goal of every company is to gain profit and advantage ([11]:72). In order to guarantee its business sustainability, a company must not only focus on getting profit, but also care about the condition of society and the situation of surrounding environment. By preserving the environment, the company is able to gain benefit indirectly, both in terms of health and convenience, as well as resources availability.

Research by Shi and Ban (2016), Salama (2004), Hilmi (2016) and Rosyid (2015) demonstrated a positive relationship between environmental performance and financial performance. The reason being that higher environmental responsibility will show better environmental performance and will result to a better financial performance as well [18]. Among six studies, four of them support the aforementioned theory, therefore the formulation of the hypothesis is as follows:

\section{$\mathbf{H}_{2}$ : Environmental Performance positively affects the Financial Performance}




\subsection{The impact of social performance and financial performance}

A company's social performance is defined as a configuration of business organisation principles of social responsibility and social response processes, also the programmes and results can be seen as a relationship between the company and society [25]. This is in line with the triple bottom line theory which says that a company must have concern as to people's welfare. A company has responsibility to provide various activities which cause positive impacts on people, considering its operational impacts that could harm them. Through a company's responsibility to the public, its reputation will be considered to be increasing, thereby improving its financial performance. Epstein (2010) explained that balancing the social aspect and financial performance is a challenge for both profit and non-profit companies at all managerial levels. Orlitzky et al. (2003) stated that, in referring to stakeholder theory, the relationship between social performance and financial performance is positive. This is due to the satisfaction of various parties who are the company's stakeholders giving positive impacts on the organisation's financial performance. Referring to stakeholder theory, companies with good social performance are expected to prioritise their shareholders' interests, reduce their business risk and improve their financial performance and market performance [26].

Research by Fischer and Sawczyn (2013), Waddock and Graves (1997), Rokhmawati et al. (2015) and Hilmi (2016) show positive relationship between a company's social performance and its financial performance, where better social performance can lead to better financial performance. According to Hilmi (2016), the condition proves that the higher a company's social responsibility in showing better social performance this will affect its financial performance to be better as well. Based on previous research, the formulation of the hypothesis is as follows:

\section{$\mathbf{H}_{3}$ : Social Performance positively affects the Financial Performance}

\section{Data}

The population in this study is the number of companies participating in PROPER which have been listed on the Indonesia Stock Exchange (IDX) in the year of 2013-2016. This research data collection is done by selecting companies that achieve five colour indicators in PROPER assessments, which are gold, green, blue, red and black. Samples of this study are obtained using purposive sampling and 87 PROPER participating companies listed on the Indonesia Stock Exchange during 2013-2016 have been 
obtained. The method utilised to measure carbon emission disclosure is retrieved from a checklist based on the demand sheet obtained from the Carbon Disclosure Project (CDP). Environmental performance is measured using PROPER assessments from the annual reports and sustainability reports. Social performance is measured using social reporting performance scores through the analysis provided by the Global Reporting Initiative (GRI) G4 Guidelines. Meanwhile, the financial performance is measured using Return on Asset (ROA).

\section{Methodology}

\subsection{Dependent variables}

Dependent variable in this research is the company's financial performance. It is one of the overall performance measurements of strategic objectives the company has achieved [15]. One of measurements to evaluate company's financial performance is ROA (Return on Asset). ROA is one of the accounting-based measurements employed to assess company's operational and financial performances (Klapper \& Love, 2002). ROA provides information about how efficient the management utilises the assets to obtain profit [40]. ROA is calculated as company's operational income before depreciation, divided by the assets [20]. ROA can also be calculated as the ratio of company's net income of the current period to the total assets of the current period [32]. The following is the ROA calculation formula:

$$
\text { ROA }=\frac{\text { Net Proft After Tax }}{\text { Total Assets }}
$$

\subsection{Independent variables}

The independent variables in this research are disclosures of carbon emissions, environmental performance and social performance. Carbon emission disclosure is a disclosure to assess an organisation's carbon emissions and set the target to reduce them [4]. Disclosure of carbon emissions can be found in the annual report and sustainability report [6]. Carbon emissions disclosure in this study is evaluated using the Carbon Disclosure Project (CDP). The CDP is a non-profit organisation created in 2000 at the initiative of institutional investors groups who are interested in incorporating information about business carbon emissions into their analysis and assessment [8]. According to Choi et al. (2013), carbon emissions disclosure uses five indicators of Carbon Disclosure Project (CDP) as follows: Climate Change (CC) risks and opportunities, Greenhouse Gas 
(GHG) emissions, Energy Consumption (EC), Reduction of Greenhouse Gas and its cost $(\mathrm{RC} / \mathrm{GHG})$ and carbon emissions accountability (AEC). The Carbon Emission Disclosure (CDP) calculation formula is as follows:

$$
\text { CDP index }{ }_{i, t}=\frac{\text { Total CDP disclosed by company } X 100 \%}{\text { Total Disclosures }}
$$

Environmental performance is a performance of a company that cares about the environment by producing environmentally friendly products [9]. Environmental performance is a demand that a company needs to fulfil as a result of pressures from employees, people, communities who concern about the environment and government as regulators [16]. Environmental performance in Indonesia can be measured using Corporate Performance Rating Program (PROPER/Program Penilaian Peringkat Kinerja Perusahaan) by the Ministry of Environment. The PROPER rating consists of five colours, which are: gold, green, blue, red and black, where the gold colour is the highest rank that indicates very good performance, meanwhile black is for the lowest rating, which indicates the poorest performance. Data taken from companies achieving the five colour indicators in PROPER during 2013-2016 are based on their annual reports and sustainability reports.

A company's social performance emerges with a concept whereby a company voluntarily integrates the social and environmental concerns into its business operations as well as its interactions with the stakeholders [36]. The company's social performance illustrates how a company's performance reflects its social responsibility and how a company can optimise every opportunity related to its business and social relationships [5]. The social performance in this study incorporates the measurement of social reporting performance scores through the analysis provided by the Global Reporting Initiative (GRI) G4 Guidelines written in the company's sustainability report. The GRI is the most widely used sustainability reporting guidelines in the world that provides recommendations on how to disclose sustainability data [39]. This study employs 48 items of social indicators based on GRI. The social performance calculation formula is as follows:

$$
\text { GRI index }{ }_{i, t}=\frac{\text { Total GRI disclosed by company } X_{100 \%}}{\text { Total Disclosures }}
$$

To examine the relationship between independent and dependent variables, this study develops a multiple regression model, where $t$-test is used to check the proposed hypothesis. The regression model used in this research is as follows: ( $\alpha$ is noted for constant variable; $\beta_{1}, \beta_{2}, \beta_{3}$ are noted for regression coefficients; $X_{I}, X_{2}, X_{3}$ are accounted for independent variables; e is noted for error).

$$
Y=\alpha+\beta_{1} X_{I}+\beta_{2} X_{2}+\beta_{3} X_{3}+e
$$




\section{Results and Analysis}

TABLE 1: Descriptive statistics.

\begin{tabular}{l|c|c|c|c|c|} 
& $\mathbf{N}$ & Minimum & Maximum & Mean & Std. Deviation \\
\hline ROA & 87 & -0.1872 & 0.5583 & 0.083760 & 0.1205239 \\
\hline CDP & 87 & 0.2222 & 1.0000 & 0.841635 & 0.1637402 \\
\hline GRI & 87 & 0.0625 & 0.9375 & 0.364943 & 0.2120992 \\
\hline
\end{tabular}

The description of these variables is presented in Table 1. Based on the table, the average value of financial performance (ROA) during the observation year is 0.083760 with standard deviation value of 0.1205239 . In this study, the highest value of financial performance reaches 0.5583 , while the lowest value is -0.1872 . The carbon emissions disclosure (CDP), which has been implemented by the company in its annual report and sustainability report, is at least 0.2222 , meanwhile the highest value of carbon emissions disclosure is 1 . It shows that a company that achieves a perfect score, which is 1, has revealed 18 items of its carbon emissions disclosure based on Carbon Disclosure Project (CDP). The average value of social performance (GRI) during the observation year is 0.364943 with standard deviation value of 0.2120992 . In this study, the highest social performance value reaches 0.9375 , while the lowest social performance value is 0.0625

TABLE 2: PROPER.

\begin{tabular}{|l|c|c|}
\hline Category & Frequency & Percentage \\
\hline Biru & 50 & 57.5 \\
\hline Hijau & 24 & 27.6 \\
\hline Emas & 13 & 14.9 \\
\hline Total & 87 & 100.0 \\
\hline
\end{tabular}

According to Table 2, the total frequency is 87 with details as follow; blue PROPER rank frequency of 50 indicates the percentage of $57.5 \%$, green PROPER rank frequency of 24 indicates the percentage of $27.6 \%$, while gold PROPER rank of 13 shows the percentage of $14.9 \%$.

Based on Table 3, the multiple linear regression equation can be obtained as follows:

$$
\text { ROA }=-0.167+0.160 \text { CDP }+0.031 \text { PROPER }-0.019 \text { GRI }
$$

From the aforementioned calculation, it can be concluded that the carbon emissions disclosure (CDP) and environmental performance (PROPER) show a positive sign which also means that there is a direct relationship between CDP and PROPER with ROA. 
TABLE 3: The result of Multiple Linier Coefficient Analysis.

\begin{tabular}{l|c|c|c|}
\hline Variable & \multicolumn{2}{|c|}{ Unstandardized Coefficients } & $\begin{array}{c}\text { Standardised } \\
\text { Coefficients }\end{array}$ \\
\hline & B & Std. Error & Beta \\
\hline (Constant) & -0.167 & 0.068 & \\
\hline CDP & 0.160 & 0.069 & 0.255 \\
\hline PROPER & 0.031 & 0.015 & 0.227 \\
\hline GRI & -0.019 & 0.049 & -0.039 \\
\hline
\end{tabular}

While the social performance (GRI) shows a negative sign, which means that there is an opposite relationship between GRI and ROA.

TABLE 4: The result of hypothesis testing.

\begin{tabular}{|l|c|c|}
\hline Variable & \multicolumn{1}{|c|}{ Sig. } \\
\hline (Constant) & -2.457 & 0.016 \\
\hline CDP & 2.336 & 0.022 \\
\hline PROPER & 2.079 & 0.041 \\
\hline GRI & -0.384 & 0.702 \\
\hline
\end{tabular}

Table 4 illustrates that the significance value of carbon emissions disclosure (CDP) and environmental performance (PROPER) is smaller than 0.05 , so it can be concluded that carbon emissions disclosure and environmental performance have significant positive impacts on financial performance. Therefore, $\mathrm{H}_{1}$ and $\mathrm{H}_{2}$ in this study are proven. However, the significance value of social performance (GRI) is greater than 0.05 , so it can be concluded that social performance does not have significant impacts on financial performance. Therefore, $\mathrm{H}_{3}$ in this study is not proven.

\subsection{Effects of carbon emission disclosure and financial performance}

Carbon emissions disclosure has significant positive impacts on financial performance. It shows that the more companies disclose their carbon emissions, the better their financial performance will be. The result of this study is in line with Healy and Palepu (2001) and Ennis et al. (2012) which stated that the more companies in Indonesia disclose their carbon emissions, the better their financial performance will be or increase. According to Ennis et al. (2012), companies that disclose their carbon emissions should enable the stakeholders to make decisions regarding the companies' condition of carbon emissions performance, encourage companies to reduce their carbon emissions, give contribution to public debates of policies, as well as regulations on climate change. 
Healy and Palepu (2001) claimed that voluntary disclosure by companies can improve their financial statements quality; therefore, potential investors are willing to invest. When a company discloses its carbon emissions, then it can be considered responsible for its environment. As such, the company is able to increase its stakeholders' confidence, which will also increase its business profit. This study explains that the more companies in Indonesia disclose their carbon emissions, the more they will be considered capable to utilise their energy resources efficiently, by reducing greenhouse gas emissions and protecting ecological balance. In addition, they are also considered responsible for their environment; therefore, communities and stakeholders are interested in buying their products. When the company gains bigger sales, then its financial performance will increase as well. However, this study is not in line with the research by Liu et al. (2016), stating that reducing carbon emissions allows companies to lower their operational costs, increase their reputation, improve their stakeholders' loyalty and increase their financial performance.

\subsection{Effects of environmental performance and financial performance}

Environmental performance has significant positive impacts on financial performance. This indicates that the better a company's environmental performance, the better its financial performance will be. The results of this study are in line with research by Shi and Ban (2016), Salama (2004), Hilmi (2016) and Rosyid (2015). The positive relationship between environmental performance and financial performance in this study is because of companies in Indonesia which have reported their environmental performance through PROPER ratings having had their financial performance improved as well. When a company is considered to possess high environmental responsibility, then the opportunity to obtain higher sales will be wide open, so that its financial performance will increase. Therefore, companies which spend heavily for environmental improvement and sustainability for the community can have positive impacts on their financial performance. The statement is in line with the triple bottom line theory, which states that the basic goal of every company is to gain profit and advantage ([11]:72). In order to guarantee a company's business sustainability, a company must not focus on getting profit only, but also care about the condition of society and environment; by preserving the environment, the company is able to gain indirect benefits, both in terms of health and convenience, as well as resources availability. Given the environmental performance assessment results by the Ministry of Environment, stakeholders 
can assess whether the PROPER participating companies listed in the Indonesia Stocks Exchange have carried out their activities based on the concepts of environmental friendliness and sustainable growth. In addition, the corporate compliance with the environmental regulations can prevent sanctions and give positive value to the company itself from the investors' points of view. However, this study is not in line with Rokhmawati et al. (2015) and Sarumpaet (2005), who suggested that a company that prepares reports related to the environmental performance would be detrimental to the company itself, both in terms of cost and time.

\subsection{Impacts of social performance and financial performance}

Social performance cannot affect the increase and decrease of company's financial performance. The result of this study is not in line with Fischer and Sawczyn (2013), Waddock and Graves (1997), Rokhmawati et al. (2015) and Hilmi (2016), who concluded that improved social performance might lead to improve a company's financial performance. According to Rosyid (2015), companies that spend heavily on social activities for the community do not need to worry, because that huge cost will not affect their financial performance. Conditions of these research samples indicate that companies in Indonesia that disclose their high social performance does not mean that those companies have a high financial performance as well, and vice versa. This is due to the fact that companies that have high returns automatically reserve some of their costs for social performance. Additionally, corporate donations are not properly targeted, as the community itself does not need those donations. Although the company is socially responsible and trying to improve its corporate image, the community is considered unaware and not loyal to the company. Thus, money spent on social performance will not affect the increase or decrease in financial performance. In this study, public demand is not as strong as environmental pressures. This indicates that financial performance is not only influenced by social performance, but also by other aspects. Therefore, social performance does not have significant impacts on financial performance and is perceived as merely an image, not because the company cares about its social responsibility.

\section{Conclusion}

This study aims to examine the impacts of carbon emission disclosure, environmental performance and social performance, on the financial performance using Return on 
Assets (ROA) as a proxy. Carbon emissions disclosure using Carbon Disclosure Project (CDP) shows significant positive impacts on financial performance. Environmental performance using PROPER ratings as the assessment criteria shows significant positive impacts on financial performance. Meanwhile, social performance using Global Reporting Initiative (GRI) shows insignificant impacts on financial performance.

This study has limitations that can be used as considerations for further research materials. First, the companies taken as samples in this research number only 87 with an observation period during the years of 2013-2016. Second, in assessing the area of carbon emissions disclosure, the researcher is using an index developed by Choi et al. (2013) without adjusting to the existing conditions in Indonesia. Third, the financial performance in this study only utilises ROA measurement.

Given these limitations, it is expected that future research can improve the limitations in this research. First, further research is expected to develop the measurements for carbon emissions disclosure which are suitable with existing conditions in Indonesia. Second, further research areas are expected to use a longer research duration, for example, five years, in order to achieve better results. Third, further research is expected to use other available proxies besides ROA for financial performance measurement.

\section{References}

[1] Andrew, Jane and Corinne L. Cortese. 2011. Carbon Disclosures: Comparability, the Carbon Disclosure Project and the Greenhouse Gas Protocol. Australasian Accounting, Business and Finance Journal, 5 (4): 5-18.

[2] Anggraeni, Dian Yuni. 2015. Pengungkapan Emisi Gas Rumah Kaca, Kinerja Lingkungan, dan Nilai Perusahaan (Greenhouse Gas Emission Disclosure, Environmental Performance, and Firm Value). Jurnal Akuntansi dan Keuangan Indonesia, 12 (2): 188209.

[3] Borghei, Zahra, Philomena Leung, and James Guthrie. 2016. The Nature Of Voluntary Greenhouse Gas Disclosure - An Explanation Of The Changing Rationale: Australian Evidence, Meditari Accountancy Research, 24 (1): 111-133.

[4] Cahya, Bayu Tri. 2016. Carbon Emission Disclosure: Ditinjau Dari Media Exposure, Kinerja Lingkungan Dan Karakteristik Perusahaan Go Public Berbasis Syariah Di Indonesia. Nizham Journal of Islamic Studies, 5 (2): 157-175.

[5] Carroll, Archie B. 1999. Corporate Social Responsibility. Business \& Society, 38 (3): 268-295. 
[6] Choi, Bae Bo, Doowon Lee, and Jim Psaros. 2013. An Analysis of Australian Company Carbon Emission Disclosures. Pacific Accounting Review, 25 (1): 58-79. DOI $10.1108 / 01140581311318968$.

[7] Deegan, Craig and Christopher Bloomquist. 2006. Stakeholders Influence on Corporate Reporting: An Exploration of Interaction between WWF Australian and Australian Minerals Industry, Accounting Organizations and Society, 31: 343-372.

[8] Depoers, Florence, Thomas Jeanjean, and Tiphaine Je'ro^me. 2016. Voluntary Disclosure of Greenhouse Gas Emissions: Contrasting the Carbon Disclosure Project and Corporate Reports. Journal Business and Ethics, 134: 445-461.

[9] Djuitaningsih, Tita dan Erista Eka Ristiawati. 2011. Pengaruh Kinerja Lingkungan dan Kepemilikan Asing Terhadap Kinerja Finansial Perusahaan. Jurnal Akuntansi Universitas Jember, 9 (2): 31-54.

[10] Eduardus, Edbert dan Juniarti. 2016. Kinerja Sosial Perusahaan dan Kinerja Keuangan Perusahaan yang Diukur Menggunakan Tobin's q. Business Accounting Review, 4 (1): 517-528.

[11] Elkington, J. 1997. Canibal With Work: The Triple Botoom Line in $21^{\text {st }}$ Century Business. Gabriola Island, BS: New Society Publisher.

[12] Ennis, C, J. Kottwitz, S.X. Lin, and N. Markusson. 2012. Exploring The Relationships Between Carbon Disclosure And Performance In FTSE 350 Companies. Working Paper. DOI: 10.1016/j.sbspro.2014.11.059.

[13] Epstein, Mark J. 2010. The Challenge of Simultaneously Improving Social and Financial Performance New Research Results Studies in Managerial and Financial Accounting. Performance and Management Control: Innovative Concept and Practices, 20): 3-18.

[14] Fischer, Thomas M. And Angelika A. Sawczyn. 2013. The Relationship Between Corporate Social Performance and Corporate Financial Performance and The Role Of Innovation: Evidence From German Listed Firms. Journal of Management Control, 24 (1): 27-52. DOI 10.1007/s00187-013-0171-5.

[15] Friedman, M. 1970. The Social Responsibility of Business is to Increase Its Profits. New York Times Magazine, 13: 32-33.

[16] Greeno, J. Ladd and S. Noble Robinson. 1992. Rethinking Corporate Environmental Management. Columbia Journal of World Business Fall \& Winter, 27 (3): 222-232.

[17] Healy, Paul M. and Krishna G. Palepu. 2001. Information Asymmetry, Corporate Disclosure, and the Capital Markets: A Review of the Empirical Disclosure Literature. Journal of Accounting and Economics, 31 (1-3): 405-440. 
[18] Hilmi. 2016. Effect Of Social And Environmental Performance Financial Performance Of The Company. European Journal of Accounting, Auditing and Finance Research, 4 (9): 30-59.

[19] Irwhantoko dan Basuki. 2016. Carbon Emission Disclosure: Studi Pada Perusahaan Manufaktur Indonesia. Jurnal Akuntansi dan Keuangan, 18 (2): 92-104. ISSN 14110288. DOI: 10.9744/jak.18.2.92-104.

[20] Jacobs, Brian W., Richard Kraude, and Sriram Narayanan. 2016. Operational Productivity, Corporate Social Performance, Financial Performance, and Risk in Manufacturing Firms. Production and Operations Management, 25 (12): 2065-2085.

[21] Kardono. 2010. Memahami Perdagangan Karbon. Pusat Standardisasi dan Lingkungan, Kementerian Kehutanan. 12 (1): 2-15. ISSN 1693-6078.

[22] Lako, Andreas. 2011. Dekonstruksi CSR \& Reformasi Paradigma Bisnis \& Akuntonsi. Jakarta: Erlangga.

[23] Liu, Yang Stephanie, Xiaoyan Zhou, Jessica H Yang, and Andreas G F Hoepner. 2016. Corporate Carbon Emission and Financial Performance: Does Carbon Disclosure Mediate the Relationship in the UK?. Discussion Paper. ICM-2016-03.

[24] Mahmood, Zeeshan, Zubair Ahmad, Waris Ali, and Aneela Ejaz. 2017. Does Environmental Disclosure Relate to Environmental Performance? Reconciling Legitimacy Theory and Voluntary Disclosure Theory. Pakistan Journal of Commerce and Social Sciences, 11 (3): 1134-1152.

[25] Orlitzky, Marc. 2001. Does Firm Size Comfound the Relationship Between Corporate Social Performance and Firm Financial Performance?. Journal of Business Ethics, 33: 167-180.

[26] Orlitzky, Marc, Frank L. Schmidt, and Sara L. Rynes. 2003. Corporate Sosial And Financial Performance: A Meta-Analysis. Organization Studies, 24 (3): 403-441.

[27] Porter, M. E and Class Van der Linde. 1995. Green and Competitive: Ending The Stalemate. Harvard Business Review, 73: 120-134.

[28] Riebeek, Holli. 2010. Global Warming, (Online). (https://earthobservatory.nasa. gov/Features/GlobalWarming/ diakses 6 January 2018).

[29] Rokhmawati, Andewi, Milind Sathye, and Suneeta Sathye. 2015. The Effect of GHG Emission, Environmental Performance, and Social Performance on Financial Performance of Listed Manufacturing Firms in Indonesia. Procedia-Social and Behavioral Sciences 211, 461-470.

[30] Rosyid, Ahmad. 2015. Pengaruh Kinerja Sosial Dan Kinerja Lingkungan Terhadap Kinerja Keuangan. Jurnal Penelitian, 12 (1): 72-85. 
[31] Salama, Aly. 2005. A Note on The Impact of Environmental Performance on Financial Performance. Structural Change and Economic Dynamics, 16): 413-421.

[32] Sardo, Filipe and Zélia Serrasqueiro. 2016. Intellectual Capital and Financial Performance Considering the Crisis Period: A European Empirical Study. Proceedings of the European Conference on Intellectual Capital, pp. 279-287.

[33] Sarumpaet, Susi. 2005. The Relationship Between Environmental Performance and Financial Performance of Indonesian Companies. Jurnal Akuntansi dan Keuangan, 7 (2): 89-98.

[34] Satya, Yuansyah. 2013. Dunia Industri Sebabkan Pemanasan Global, (Online). (http: //www.neraca.co.id/article/27753/dunia-industri-sebabkan-pemanasan-global diakses 15 January 2018).

[35] Shi, Xiao Yan and Jing Gang Ban. 2016. The Research on the Relationship Between Environmental Performance and Financial Performance. Journal of Finance and Accounting, 4 (2): 81-85.

[36] Skudiene, Vida, Christine McClatchey, and Agne Kancleryte. 2012. Strategic Versus Ad-hoc Corporate Social Performance: An Analysis of CSP Maturity and Its Relationship to Corporate Financial Performance. Journal of Management and Sustainability, 3 (1): 16-32. DOI 10.5539/jms.v3n1p16.

[37] Suparjan, Andika dan Ali Sandy Mulya. 2012. Pengaruh Kinerja Sosial Dan Kinerja Keuangan Perusahaan Dengan Pengungkapan Corporate Social Responsibility(Csr) Sebagai Variabel Intervening Terhadap Nilai Perusahaan. Media Riset Akuntansi, Auditing \& Informasi, 12 (3): 27-58.

[38] Waddock, Sandra A. and Samuel B. Graves. 1997. The Corporate Social PerformanceFinancial Performance Link. Strategic Management Journal, 18 (4): 303-319.

[39] Wagner, Rea and Peter Seele. 2017. Uncommitted Deliberation? Discussing Regulatory Gaps by Comparing GRI 3.1 to GRI 4.0 in a Political CSR Perspective. Journal Business and Ethics, 146: 333-351.

[40] Widhiastuti, Ni Luh Putu, I D. G Dharma Saputra, dan I G. A. N. Budiasih. 2017. Pengaruh Kinerja Lingkungan Pada Kinerja Keuangan Dengan Corporate Social Responsibility Sebagai Variabel Intervening. E-Jurnal Ekonomi dan Bisnis Universitos Udayana 6.2, 819-846. 